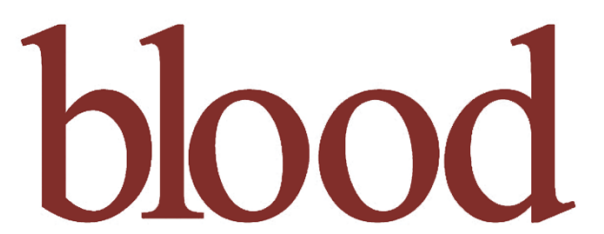

2004 104: $1281-1290$

Prepublished online May 13, 2004;

doi:10.1182/blood-2003-09-3044

\title{
Sustained correction of B-cell development and function in a murine model of X-linked agammaglobulinemia (XLA) using retroviral-mediated gene transfer
}

Phyllis W. Yu, Ruby S. Tabuchi, Roberta M. Kato, Alexander Astrakhan, Stephanie Humblet-Baron, Kevin Kipp, Keun Chae, Wilfried Ellmeier, Owen N. Witte and David J. Rawlings

Updated information and services can be found at:

http://bloodjournal.hematologylibrary.org/content/104/5/1281.full.html

Articles on similar topics can be found in the following Blood collections

Free Research Articles (1333 articles)

Gene Therapy (495 articles)

Immunobiology (4699 articles)

Information about reproducing this article in parts or in its entirety may be found online at:

http://bloodjournal.hematologylibrary.org/site/misc/rights.xhtml\#repub_requests

Information about ordering reprints may be found online at:

http://bloodjournal.hematologylibrary.org/site/misc/rights.xhtml\#reprints

Information about subscriptions and ASH membership may be found online at:

http://bloodjournal.hematologylibrary.org/site/subscriptions/index.xhtml

Blood (print ISSN 0006-4971, online ISSN 1528-0020), is published weekly

by the American Society of Hematology, 2021 L St, NW, Suite 900,

Washington DC 20036.

Copyright 2011 by The American Society of Hematology; all rights reserved.

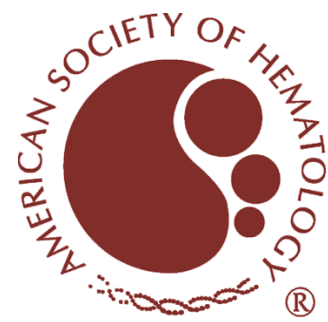




\title{
Sustained correction of B-cell development and function in a murine model of $\mathrm{X}$-linked agammaglobulinemia (XLA) using retroviral-mediated gene transfer
}

Phyllis W. Yu, Ruby S. Tabuchi, Roberta M. Kato, Alexander Astrakhan, Stephanie Humblet-Baron, Kevin Kipp, Keun Chae, Wilfried Ellmeier, Owen N. Witte, and David J. Rawlings

\begin{abstract}
$\mathrm{X}$-linked agammaglobulinemia (XLA) is a human immunodeficiency caused by mutations in Bruton tyrosine kinase (Btk) and characterized by an arrest in early B-cell development, near absence of serum immunoglobulin, and recurrent bacterial infections. Using Btk- and Tecdeficient mice (BtkTec ${ }^{-1-}$ ) as a model for $X L A$, we determined if Btk gene therapy could correct this disorder. Bone marrow (BM) from 5-fluorouracil (5FU)-treated $\mathrm{BtkTec}^{-/-}$mice was transduced with a retroviral vector expressing human Btk and transplanted into $\mathrm{BtkTec}^{-/-}$recipi-
\end{abstract}

ents. Mice engrafted with transduced hematopoietic cells exhibited rescue of both primary and peripheral $B$-lineage development, recovery of peritoneal B1 B cells, and correction of serum immunoglobulin $M(\lg M)$ and $\lg G_{3}$ levels. Gene transfer also restored $\mathrm{T}$-independent type II immune responses, and $\mathrm{B}$-cell antigen receptor (BCR) proliferative responses. Bcell progenitors derived from Btktransduced stem cells exhibited higher levels of Btk expression than non-B cells; and marking studies demonstrated a selective advantage for Btk-transduced B- lineage cells. BM derived from primary recipients also rescued Btk-dependent function in secondary hosts that had received a transplant. Together, these data demonstrate that gene transfer into hematopoietic stem cells can reconstitute Btkdependent B-cell development and function in vivo, and strongly support the feasibility of pursuing Btk gene transfer for XLA. (Blood. 2004;104:1281-1290)

(C) 2004 by The American Society of Hematology

\section{Introduction}

$\mathrm{X}$-linked agammaglobulinemia (XLA) is the prototypic primary humoral immunodeficiency disorder, first described by Bruton who reported a boy with severe recurrent infections and absence of the gamma-globulin serum fraction. ${ }^{1}$ This disorder has been of major interest for more than half a century, initiating an ongoing and fruitful search for the genetic basis of this and other primary immunodeficiency diseases.

XLA is characterized by a lack of mature B cells and plasma cells and a profound deficiency of all immunoglobulin types. Most patients develop recurrent infections coincident with the loss of maternal antibodies. Pyogenic infection with encapsulated bacteria is the most common clinical manifestation..$^{2-4}$ Current therapy consists of regular immunoglobulin replacement and prompt attention to infection.

Both XLA and a related murine immunodeficiency, X-linked immunodeficiency (Xid), result from deficiencies in Bruton tyrosine kinase (Btk). ${ }^{5-10}$ Btk, a member of the Tec family of nonreceptor kinases, ${ }^{11}$ is expressed throughout B-lineage development except in plasma cells. ${ }^{12,13}$ Btk contains a Src homology 1 (SH1) catalytic domain, $\mathrm{SH} 2$ and $\mathrm{SH} 3$ protein interaction domains, and a unique amino-terminus with a pleckstrin homology $(\mathrm{PH})$ domain. ${ }^{14}$ Mutational studies indicate important functional roles for each of these domains. ${ }^{15}$

The major developmental defect in XLA occurs at the pre-Bcell transition, resulting in an increase in pro-B cells and a marked reduction in cycling pre-B cells and all subsequent stages. ${ }^{16-18} \mathrm{Few}$ $\mathrm{IgM}^{+} \mathrm{B}$ cells are detectable in the blood and the hypotrophic lymphoid tissues. ${ }^{19,20}$ Clonal expansion at the pre-B stage is regulated by pre-B-cell receptor (pre-BCR) signaling and is essential for generating an adequate pool of immature B cells. ${ }^{21}$ Pre-BCR engagement leads to the generation of a "signalosome" that includes activated Btk, ${ }^{22}$ an event disrupted in XLA.

Several murine models of Btk deficiency currently exist. Xid mice have a spontaneous missense mutation in the $\mathrm{PH}$ domain. ${ }^{23}$ The mutant protein is inefficiently recruited to the plasma membrane and fails to enter the BCR signalosome. ${ }^{24}$ The phenotype of both Xid mice and Btk null-knockout mice $\left(\mathrm{Btk}^{-/-}\right)$is less severe than that of XLA. ${ }^{25-28}$ These mice produce nearly normal numbers of peripheral B cells, but splenic B-cell development is significantly compromised. Btk-deficient transitional 2 (T2) immature B cells fail to generate the BCR-dependent pro-survival, proliferative, and differentiation signals required to produce mature $\mathrm{B}$
From the Molecular Biology Institute, the Howard Hughes Medical Institute, the Department of Microbiology and Molecular Genetics, and the Department of Pediatrics, University of California at Los Angeles; the Departments of Immunology and Pediatrics, University of Washington School of Medicine Seattle; and the Institute of Immunology, Medical University Vienna, Austria.

Submitted September 4, 2003; accepted April 15, 2004. Prepublished online as Blood First Edition Paper, May 13, 2004; DOI 10.1182/blood-2003-09-3044.

Supported by a National Institutes of General Medical Sciences National Research Service Award (P.W.Y.), a McDonnell Scholar Award (D.J.R.), a Leukemia and Lymphoma Society Scholar Award (D.J.R.), the Joan J. Drake Grant for Excellence in Cancer Research (D.J.R.), grants from National
Institutes of Health (HD37091, CA81140, AI38348, and AI33617; D.J.R.), and the American Cancer Society (D.J.R.).

An Inside Blood analysis of this article appears in the front of this issue.

Reprints: David J. Rawlings, Children's Hospital and Regional Medical Center, 307 Westlake Ave North, Suite 300, Seattle, WA 98109; e-mail: drawling@u.washington.edu.

The publication costs of this article were defrayed in part by page charge payment. Therefore, and solely to indicate this fact, this article is hereby marked "advertisement" in accordance with 18 U.S.C. section 1734.

(C) 2004 by The American Society of Hematology 
cells..$^{29,30}$ Consistent with these findings, the BCR-dependent calcium signal is markedly reduced in Btk-deficient B cells. ${ }^{31-33}$ Thus, Btk plays a crucial role in both primary B lymphopoiesis in the marrow and in splenic peripheral B-lineage development and signaling.

The difference between Btk-deficient humans and mice is partially attributable to the redundant function of Tec. Mice deficient for Btk and Tec (BtkTec ${ }^{-/-}$) exhibit an early, severe block in B-lineage development that is nearly identical to XLA. ${ }^{34} \mathrm{Tec}$ is expressed throughout B-lineage development, but at a lower level than Btk (D.J.R., unpublished data, January 2002). While this level of Tec is sufficient to rescue murine pre-B transition, a much higher $\mathrm{Btk} / \mathrm{Tec}$ dosage is required for mature B-cell signaling in both mice and humans. Overexpression of Tec can rescue BCR-dependent signals in Btk-deficient B cells, ${ }^{33,35}$ but endogenous Tec is insufficient to restore these events. The inability of residual Tec to rescue human pre-B-cell development is consistent with a more stringent requirement for all components of the pre-BCR complex in humans. ${ }^{36}$

Several lines of evidence demonstrate a strong selective advantage for B-lineage cells expressing wild-type (WT) Btk. Female carriers of XLA exhibit nonrandom X-inactivation of the mutant allele specifically within the B-cell compartment. ${ }^{37}$ Transplantation of mixtures of $\mathrm{CBA} / \mathrm{J}$ (WT) and $\mathrm{CBA} / \mathrm{N}$ (Xid) BM cells into lethally irradiated Xid mice also leads to the selective expansion and survival of WT B cells. ${ }^{38}$ Immune responses can also be restored in sublethally irradiated mice with as few as $2.5 \times 10^{4}$ total $\mathrm{BM}$ cells. ${ }^{39}$ In addition, larger numbers of $\mathrm{BM}$ or fetal liver cells can rescue B-lineage development in the absence of myeloablation. ${ }^{40-42}$ These observations suggest that even under suboptimal conditions, hematopoietic-targeted Btk gene therapy might promote long-term restoration of B-cell function in XLA.

The availability of murine models offers the opportunity to evaluate gene therapy as an alternative treatment for XLA. We tested the capacity of a modified Moloney murine leukemia virus retroviral vector expressing human Btk to implement hematopoieticbased Btk gene therapy in $\mathrm{BtkTec}^{-1-}$ mice, the model most representative of XLA. Our results demonstrate the progressive outgrowth of Btk-expressing B cells and restoration of Btkdependent B-lineage development and functional responses.

\section{Materials and methods}

\section{Retroviral vectors and producer cell lines}

The murine stem cell virus (MSCV) backbone was used to enhance sustained expression in hematopoietic cells. ${ }^{43}$ Briefly, the vector MSCVhuBtk-SAR (subsequently referred to as MBS; Figure 1A) was generated as follows: human $\beta$-interferon scaffold attachment region (SAR) ${ }^{44}$ obtained as an 877-bp fragment after $\mathrm{XhoI}$ and $\mathrm{ClaI}$ digestion of pMND-IRES-GFPSAR (kindly provided by Dr Donald Kohn, University of Southern California [USC]), was inserted into the $C l a$ I site of MSCV-ires-GFP ${ }^{45}$ by a blunt-end ligation following end-fill reaction. Full-length human BTK coding sequence (98\% identical with murine Btk protein) $)^{12}$ was then inserted into XhoI and HindIII sites.

High-titer 10A.1 pseudotyped retrovirus, generated by cotransfection of 293-T cells with pCL packaging plasmids ${ }^{46}$ by calcium phosphate precipitation was used to infect GP+E86 producer cell lines to create the MBS producer cell line; titers were estimated by infecting interleukin-7expanded BM and evaluating transgenic Btk expression by flow cytometry. The control ecotrophic producer cell line, MSCV-ires-GFP (subsequently referred to as MIG), was generated using an identical approach. Producer lines were maintained in Dulbecco modified Eagle medium (DMEM; Mediatech, Herndon, VA) supplemented with $10 \%$ fetal bovine serum, 2
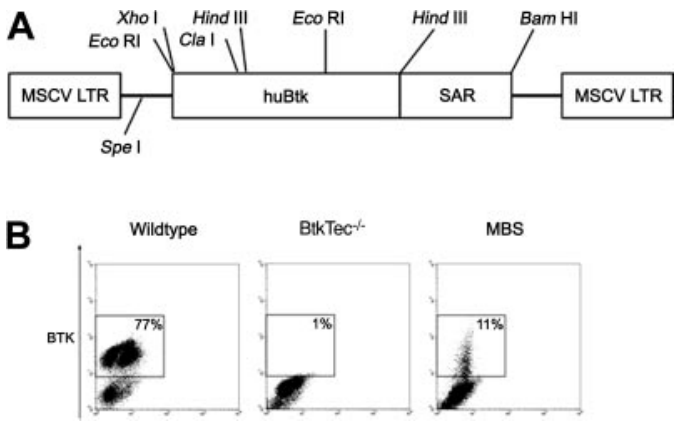

Figure 1. Transduction of 5FU-treated BM with the MBS vector. (A) Structure of the MSCV-huBtk-SAR (MBS) retroviral vector. The murine stem cell virus (MSCV) promoter drives expression of human Btk. The human interferon- $\beta$ scaffold attach ment region (SAR) was included to facilitate sustained expression of the Btk transgene in differentiated cells. (B) Btk expression in mock-transduced BM from WT and $\mathrm{BtkTec}^{-1-}$ mice, and in MBS-transduced BM from BtkTec ${ }^{-1-}$ mice. BM was analyzed immediately prior to transplantation into $\mathrm{BtkTec}^{-/-}$recipients (using intracellular FACS analysis). Btk expression in BM progenitors was between $6 \%$ and $11 \%$ in experiments 1 to 3 .

mM L-glutamine (Invitrogen, Carlsbad, CA), and $100 \mathrm{U} / \mathrm{mL}$ penicillin/ streptomycin (Invitrogen).

\section{Mice}

C57BL/6 (Jackson) mice, and BtkTec ${ }^{-1-}$ mice (generated as previously described ${ }^{34}$ ) were bred and maintained in the pathogen-free barrier facilities at the University of California at Los Angeles and the University of Washington.

\section{Transduction and transplantation}

$\mathrm{BtkTec}^{-1-}$ donor mice were injected intraperitoneally with 5-fluorouracil (5FU; $150 \mathrm{mg} / \mathrm{kg}$ body weight; Sigma, St Louis, MO) 3 days before BM harvest. Following red blood cell lysis, BM cells were cocultured directly on irradiated producer cells in complete media (RPMI; Mediatech), $10 \%$ fetal bovine serum, $2 \mathrm{mM}$ L-glutamine (Invitrogen), $50 \mu \mathrm{M} \beta$-mercaptoethanol (Sigma), $100 \mathrm{U} / \mathrm{mL}$ penicillin/streptomycin (Invitrogen) with $4 \mu \mathrm{g} / \mathrm{mL}$ polybrene (Sigma) and the following recombinant human or murine cytokines (BioSource International, Camarillo, CA): $20 \mathrm{ng} / \mathrm{mL}$ interleukin-3, $20 \mathrm{ng} / \mathrm{mL}$ interleukin-6, $20 \mathrm{ng} / \mathrm{mL}$ stem cell factor, $20 \mathrm{ng} / \mathrm{mL}$ Flt-3 ligand, and $20 \mathrm{ng} / \mathrm{mL}$ thrombopoietin. In experiments 1 to 3 , WT C57BL/6 and $\mathrm{BtkTec}^{-1-} \mathrm{BM}$ was mock-transduced on $\mathrm{GP}+\mathrm{E} 86$ parental cells. In experiment 4, WT C57BL/6 and $\mathrm{BtkTec}^{-I-} \mathrm{BM}$ was prestimulated for 48 hours in media supplemented with the identical murine cytokines (each 10 $\mathrm{ng} / \mathrm{mL}$; Peprotech, Rocky Hill, NJ) followed by cocultivation on MBS or MIG producer cells (for BtkTec ${ }^{-1-} \mathrm{BM}$ cells) or GP $+\mathrm{E} 86$ parental cells (for WT C57BL/6 BM). After 3 days of cocultivation, cells were injected into lethally irradiated $\left(11 \mathrm{~Gy}\right.$, split dose) $\mathrm{BtkTec}^{-1-}$ recipients at $1-5 \times 10^{6}$ cells/mouse by retro-orbital injection. Mice were treated with enrofloxacin $(0.5 \mathrm{mg} / \mathrm{mL}$ in the drinking water) for 2 weeks. For secondary transplants, BM was harvested from primary recipients and $5 \times 10^{6}$ cells/animal was injected into lethally irradiated $\mathrm{BtkTec}^{-1-}$ recipients.

\section{B-cell purification and semiquantitative real-time polymerase chain reaction (Q-PCR) analysis of Btk retroviral integration}

B-cell purification was carried out using magnetically coated beads (Miltenyi Biotec, Auburn, CA) according to manufacturer's instructions. Splenic B cells were enriched by negative selection using anti-CD43coated beads. Bone marrow B cells were enriched by positive selection using anti-B220-coated beads. Purity of B-cell populations was more than or equal to $85 \%$ based on fluorescence-activated cell sorting (FACS) analysis. Cell populations were pelleted and frozen for Q-PCR analysis. All PCR reagents and instrumentation were obtained from Biorad (Hercules, CA) unless otherwise noted. PCR reactions were carried out using the iCycler real-time PCR detection system with iQ SYBR Green Supermix. Efficiency and threshold cycle $(\mathrm{Ct})$ values were determined with the iCycler 
IQ optical analysis software and primers designed with Vector NTI software (InforMax, Frederick, MD) and manufactured by MWG Biotech (High Point, NC).

Q-PCR was performed on genomic DNA (using input transduced BM cells, and BM, thymus, or splenic cells derived from animals receiving a transplant), and normalized to a standard DNA derived from an A20 murine B-cell line containing a single copy of the vector MSCV-BTK-IRES-GFP (as determined by Southern blotting). DNA was isolated with QIAamp DNA mini kit (Qiagen, Valencia, CA) according to manufacturer's instructions. BTK-specific primers were designed to amplify mouse or human exon-spanning products. The mouse $\beta$-2-microglobulin $(\beta 2 \mathrm{~m})$ gene was selected as a housekeeping control. Primer sequences are available upon request. Products were amplified using a standard PCR protocol ( 35 cycles of $95^{\circ} \mathrm{C}$ for 30 seconds, $60^{\circ} \mathrm{C}$ for 30 seconds, and $72^{\circ} \mathrm{C}$ for 30 seconds) and primer specificity was determined by melt curve and ethidium bromide gel analysis. BTK or GFP integration was analyzed using the Pfaffl mathematical model for relative quantification. ${ }^{47}$ Initially, BTK, GFP, and $\beta 2 \mathrm{~m}$ primer efficiencies were determined by generating a standard curve using dilutions of A20 DNA. Threshold cycles (Cts) were then obtained by running all PCR samples in triplicate. Relative ratios of BTK or GFP expression were calculated using A20 Ct as calibrator values for all samples. All Q-PCR data included at least 3 independent analyses (with 3 replicates per analysis) and statistical significance was determined by a paired, 2-tailed Student $t$ test.

\section{Immunization and ELISA assays}

Engrafted mice were immunized intraperitoneally with $10 \mu \mathrm{g}$ trinitrophenylsubstituted (TNP)-Ficoll (Bioresearch Technologies, Novato, CA) in 100 $\mu \mathrm{L}$ phosphate-buffered saline (PBS). Mice were bled by saphenous vein puncture 7 to 10 days later. Serum was used for enzyme linked immunosorbent assays (ELISAs) and peripheral blood cells were analyzed by flow cytometry. ELISAs were used to detect TNP-specific IgM and $\operatorname{IgG}_{3}$ and total serum IgM and $\operatorname{IgG}_{3}$. Briefly, 96-well Nunc Maxisorp ELISA plates (Fisher, Pittsburgh, PA) were coated with TNP-bovine serum albumin (BSA; Bioresearch Technologies), anti-mouse IgM, or anti-mouse $\mathrm{IgG}_{3}$ (Southern Biotech, Birmingham, AL), incubated for 1 hour in a $37^{\circ} \mathrm{C}$ humidified chamber, were blocked with $\mathrm{PBS} / \mathrm{Mg}^{2+}$ (Invitrogen) plus $2 \%$ BSA, and incubated with serial dilutions of serum, followed by alkaline phosphatase-conjugated anti-mouse IgM or anti-mouse $\mathrm{IgG}_{3}$. Plates were washed with $\mathrm{PBS} / \mathrm{Mg}^{2+}$ plus $0.05 \%$ Tween-20, incubated with $\mathrm{p}$ nitrophenyl phosphate substrate (Southern Biotech), and absorbance was measured at $405 \mathrm{~nm}$ on a Bio-Rad microplate reader. Ig levels were quantified by comparison with titrated Ig standards.

\section{Flow cytometric analysis}

Single-cell suspensions prepared from BM, spleen, peripheral blood, and peritoneal washes were incubated with fluorochrome-conjugated antibodies for 1 hour on ice. Cytofix/Cytoperm (Pharmingen, San Diego, CA) was used for intracellular stains. The following primary antibodies (all from Pharmingen, except where noted) were used: phycoerythrin (PE)conjugated antimouse CD45R/B220, Cy-Chrome-conjugated antimouse CD45R/B220, fluorescein isothiocyanate (FITC)-conjugated anti-mouse IgM, PE-conjugated anti-mouse IgD (Southern Biotech), PE-conjugated antimouse CD11b/Mac1, biotin-conjugated antimouse CD43, and biotinconjugated antimouse CD5. Spectral red-conjugated streptavidin (Southern Biotech) was used to visualize biotin-conjugated antibodies. For Btk stains, affinity-purified polyclonal rabbit anti-Btk was used in conjunction with a PE-conjugated donkey anti-rabbit Ig (Jackson ImmunoResearch); all intracellular stains were performed in the presence of blocking total mouse IgG (Accurate Chemical, Westbury, NY). Cell analysis was performed using a FACSCalibur flow cytometer and CellQuest software (Becton Dickinson, San Jose, CA).

\section{B-cell proliferation assay}

Total splenocytes were seeded in 96-well flat-bottom plates at $2.5 \times 10^{5}$ cells/well in complete media with $10 \mathrm{ng} / \mathrm{mL}$ phorbol myristate acetate (PMA; Sigma) plus $1 \mu \mathrm{M}$ ionomycin (Calbiochem, San Diego, CA), 10 $\mu \mathrm{g} / \mathrm{mL}$ lipopolysaccharide (LPS; Sigma), and $20 \mu \mathrm{g} / \mathrm{mL}$ or $5 \mu \mathrm{g} / \mathrm{mL}$ goat-antimouse IgM $\mathrm{F}\left(\mathrm{ab}^{\prime}\right)_{2}$ fragment (Jackson ImmunoResearch, Westgrove, PA). ${ }^{3} \mathrm{H}$-thymidine $(1 \mu \mathrm{Ci}[37 \mathrm{KBq}]$; DuPont NEN, Boston, MA) was added after 48 hours, and cells were harvested 18 hours later and counted on a scintillation counter.

\section{Colony-forming unit-B-cell (CFU-B) assay}

Sheep red blood cells (SRBCs; Mission Labs, Los Angeles, CA) were washed extensively and stored on ice. BM cells and splenocytes were plated in duplicate on $35 \times 10-\mathrm{mm}$ culture dishes with a 2-mm grid (Nalge Nunc, Rochester, NY) at $5 \times 10^{4}$ cells/dish in $1 \mathrm{~mL}$ Iscove modification of DMEM (Mediatech) supplemented with 15\% FBS, 2 mM L-glutamine, 50 $\mu \mathrm{M} \beta$-mercaptoethanol, $25 \mathrm{mM}$ HEPES (Invitrogen), $100 \mathrm{U} / \mathrm{mL}$ penicillin/ streptomycin, $10 \mu \mathrm{g} / \mathrm{mL}$ LPS, and $10 \%$ washed SRBCs. A predissolved solution of $3 \% \mathrm{wt} / \mathrm{vol}$ bacto agar (Becton Dickinson) was kept at $55^{\circ} \mathrm{C}$ and used to add agar to the cells at a final concentration of $0.3 \%$ just before plating. Colonies were counted after 7 to 10 days by treating with $1 \mathrm{~mL} 3 \%$ acetic acid

\section{Statistical analysis}

The statistical significance of measurements of B-cell populations and function were determined using a 2-tailed $t$ test of independent sample means. Statistical analyses were performed comparing results obtained from recipient mice of MBS transduced bone marrow versus control mice that received mock-transduced (or MIG-transduced) bone marrow from $\mathrm{BtkTec}^{-/-}$mice.

\section{Results}

\section{Transduction of $\mathrm{BtkTec}^{-/-} \mathrm{BM}$ progenitors using a retroviral vector expressing human Btk}

To transfer Btk into murine hematopoietic stem cells, we generated the MBS vector containing the full-length human Btk cDNA and the human $\beta$-interferon SAR to promote sustained gene expression (Figure 1A). ${ }^{44}$ Gene transfer studies were carried out using Btk/Tec doubly deficient mice for several key reasons. First, BtkTec ${ }^{-/-}$ mice exhibit a pre-B-cell developmental block essentially identical with human XLA. ${ }^{34}$ Second, because pre-BCR signaling mediates the major $\mathrm{B}$-lineage clonal expansion in the $\mathrm{BM}$, we predicted that enforced Btk expression at this stage would strongly favor the expansion of transduced cells. Finally, we hypothesized that the stringent requirement for Btk at this checkpoint would promote expansion of cells expressing Btk at a dosage sufficient to also rescue peripheral $\mathrm{B}$-lineage function.

BM from 5FU-treated $\mathrm{BtkTec}^{-1-}$ mice was transduced by cocultivation on an ecotropic MBS producer cell line in the presence of cytokines for 3 days. In all experiments, lethally irradiated BtkTec ${ }^{-1-}$ recipients received transplants of 1 to $5 \times 10^{6}$ 5FU-treated bone marrow cells. Experiments 1 to 3 included cohorts of 2 to 5 animals that underwent transplantation with the following cells: mock-transduced WT (C57/B16) BM, mocktransduced $\mathrm{BtkTec}^{-1-} \mathrm{BM}$, a $10 \%$ mixture of $\mathrm{C} 57 / \mathrm{Bl} 6$ marrow in $\mathrm{BtkTec}^{-1-}$ marrow (designed to simulate MBS transduction), and MBS-transduced BtkTec ${ }^{-1-}$ BM. In each of these experiments, $5 \%$ to $15 \%$ of the MBS-transduced, 5FU-treated BM cells expressed exogenous Btk at the time of cell transplantation (as determined by Btk intracellular staining; Figure 1B). The mean fluorescence intensity (MFI) of Btk staining was comparable to that of endogenous Btk in WT (C57/B16) BM. In experiment 4, BM cells were prestimulated for 2 days prior to cocultivation on the MBS or MSCV-ires-GFP (MIG) producer cell lines and cohorts of 2 to 5 animals underwent transplantation with mock-transduced WT 
(C57/B16) BM, MIG-transduced BtkTec ${ }^{-1-} \mathrm{BM}$, and MBStransduced BtkTec ${ }^{-1-} \mathrm{BM}$.

\section{Btk expression is maintained and positively selected in mice undergoing transplantation with MBS}

To monitor transgenic Btk expression and reconstitution, mice that had undergone transplantation were periodically immunized and bled beginning at 5 to 6 weeks after transplantation. Animals in experiments 1 to 3 were killed at 13, 15, and 21 weeks after transplantation, respectively. Animals in experiment 4 were killed at week 14

Animals that had received transplants were initially evaluated for cellular reconstitution and transgene expression. Figure $2 \mathrm{~A}$ demonstrates the Btk expression profile for splenocytes from killed animals. Btk ${ }^{+}$cells were specifically enriched within the $\mathrm{B} 220^{+}$ splenic B-cell compartment in MBS-transduced mice. In contrast, Btk expression levels in non-B splenic cells (while clearly higher than $\mathrm{BtkTec}^{-1-}$ control cells) was significantly less than that observed in B-lineage cells. Similar results were observed for peripheral blood B versus non-B-cell populations (data not shown). The relative level of Btk expression in B-lineage versus non-Blineage cells from 3 similar experiments is illustrated in Figure 2B. In contrast to Btk expression in B220 ${ }^{+}$splenocytes, Btk expression in $\mathrm{B} 220^{-}$cells remained nearly equivalent to the expression level observed within the input, MBS-transduced stem cell population.

We also used Btk retroviral specific Q-PCR analysis to determine the viral copy number in BM and splenic cell populations isolated from MBS-treated animals (Figure 2C). These data indicated a significant enrichment for Btk marked cells within the spleen. To determine whether there was a specific increase in relative viral copy numbers in B-lineage cells, we isolated B- and non-B-lineage cells. Viral copy number was determined using Q-PCR for input transduced cells; (Figure 2D) and from purified B cells versus non-B cells (Figure $2 \mathrm{E}$ ) for each of the MBS-treated animals in experiment 4 . These data indicated a significant enrichment for viral marking within B-lineage cells in both BM and spleen. Further, these data demonstrated a significant enrichment for Btk marking of peripheral (splenic) versus primary (BM) B cells. Taken together, these observations indicate that Btkexpressing B cells exhibit a significant selective advantage, leading to their progressive accumulation within the peripheral lymphoid compartment.

\section{MBS transduction rescues B-cell development in $\mathrm{BtkTec}^{-/-}$mice}

We analyzed the relative frequency and absolute numbers of B-cell developmental subsets within the BM, spleen, peripheral blood, and the peritoneal cavity of recipient animals (Figure 3) using the schema developed by $\mathrm{Li}$ et al. ${ }^{48}$ Fractions $\mathrm{A}$ to $\mathrm{C}$, identified by expression of B220 and CD43, represent the earliest stages of B-cell development corresponding to pro-B cells. Fraction D cells, which lose $\mathrm{CD} 43$, are primarily pre-B cells. Fractions $\mathrm{E}$ to $\mathrm{F}$ (immature and mature $\mathrm{B}$ cells) are characterized by the acquisition of surface IgM. Fraction F cells emigrate to the spleen, where relative expression levels of $\operatorname{IgM}$ and $\operatorname{IgD}$ further distinguish immature, transitional, and naive mature B-cell subsets. Differentiation proceeds roughly from Fraction F3 ( $\operatorname{IgM}^{\text {hi }} / \operatorname{IgD}^{\text {lo }}$, Transitional 1) to $\mathrm{F} 2$ (IgM ${ }^{\text {hi }} / \operatorname{IgD}^{\text {hi }}$, Transitional 2) to $\mathrm{F} 1$ (IgM $\left.{ }^{\mathrm{lo}} / \operatorname{IgD}^{\text {hi }}\right)$. A similar profile is observed in peripheral blood.

Figure 3A illustrates the pre-B-developmental block in Btk-/ Tec- mice ${ }^{34}$ manifested as an accumulation of Fraction A to $\mathrm{C}$ cells (73\% of BM B220 ${ }^{+}$cells) and a relative paucity of Fraction D $(6 \%)$ and Fractions E to $\mathrm{F}(21 \%)$. This contrasts with $13 \%$ for Fractions A to C, $12 \%$ for Fraction D, and $75 \%$ for Fractions $\mathrm{E}$ to $\mathrm{F}$, respectively, in a WT recipient. In the representative MBS-treated animal, the corresponding percentages were $17 \%$ Fractions A to $\mathrm{C}$, $42 \%$ Fraction $\mathrm{D}$, and $40 \%$ Fractions $\mathrm{E}$ to $\mathrm{F}$, indicating a marked increase in later developmental B-lineage subsets compared with the $\mathrm{BtkTec}^{-1-}$ control. The block in peripheral BCR-dependent
A

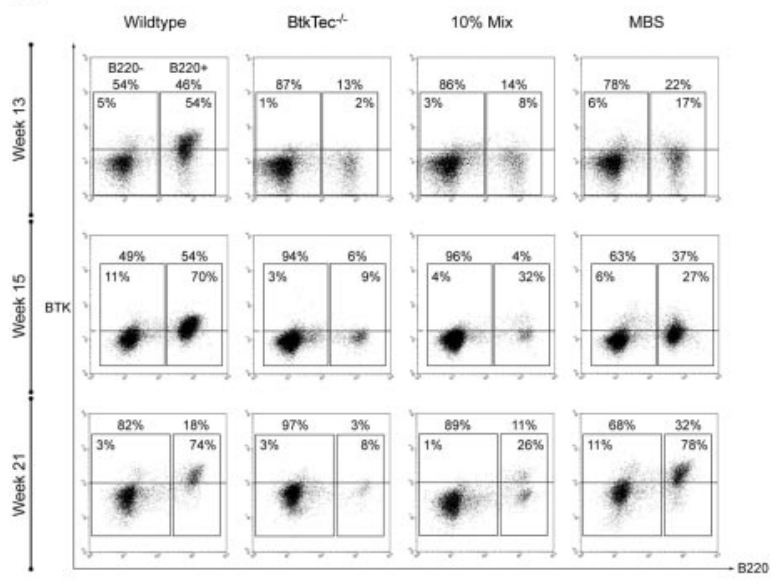

B
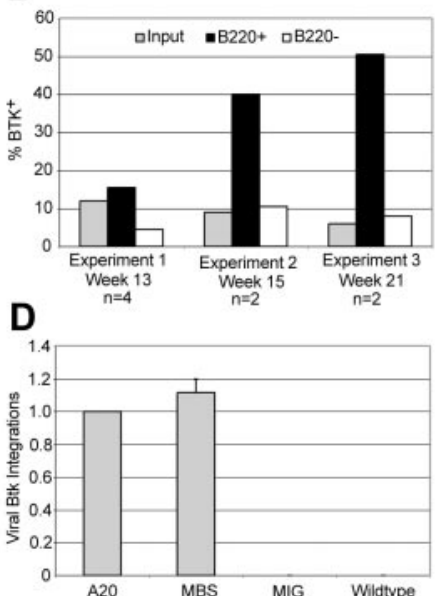

C

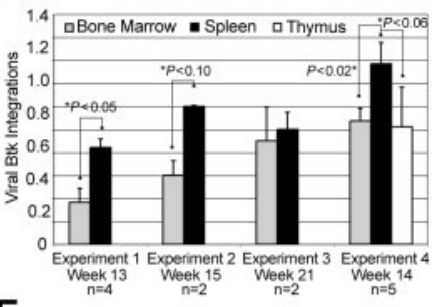

E

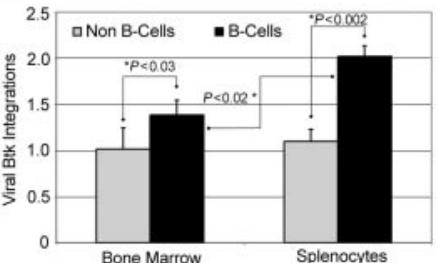

Figure 2. huBtk expression and viral marking in mice that underwent transplantation with BtkTec ${ }^{-/-}$. (A) Splenocytes were harvested from animals in experiments 1,2 , and 3 at weeks 13, 15, and 21, respectively; stained for B220; permeabilized; and stained for transgenic huBtk expression. Representative plots for each time point are shown. $\mathrm{B} 220^{-}$non-B-lineage and B220 ${ }^{+}$-lineage regions are indicated, as well as the percentages of each relative to a small lymphocyte gate on total splenocytes. The percentage of $\mathrm{Btk}^{+}$cells within each region is shown inside the region box. (B) The average percentage of Btk ${ }^{+}$cells in $\mathrm{B}^{2} 20^{+}$versus $\mathrm{B} 220^{-}$splenic populations in $\mathrm{MBS}$-treated recipients for each experiment was determined and compared to expression at the time of initial BM transduction (as measured by intracellular Btk staining prior to injection). (C) Btk viral copy number was determined using BM and spleen (as well as thymocytes in experiment 4) for all MBS-treated animals at the time of sacrifice (see "Materials and methods"). *Statistically significant differences in splenic versus BM cells. The similar level of marking of BM and spleen in experiment 3 likely reflects increasing numbers of mature recirculating B cells present in the BM by week 21 after transplantation (data not shown). (D) Btk viral copy number in a control B-cell line (A20) containing a single Btk viral integration, and in MBS-, MSCV-ires-GFP (MIG)-, or mock-transduced stem cells at the time of primary transplantation in experiment 4 . (E) Btk viral copy number in B versus non-B cells purified from either BM or spleen in experiment 4 (see "Materials and methods"). *Significant differences between relative viral copy number in B versus non-B cells, and in marking of splenic versus BM B cells $(n=5)$. Error bars indicate SD of results in panels C-E. 

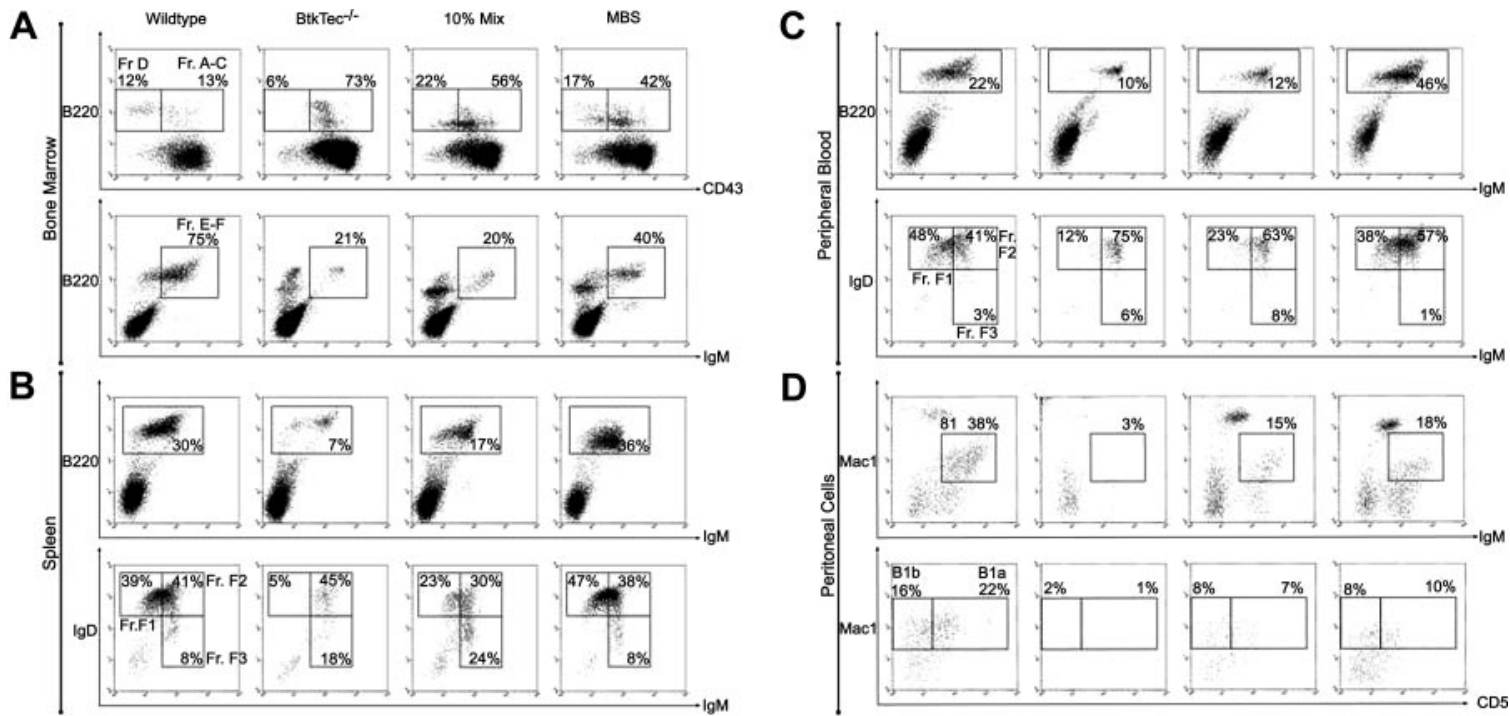

Figure 3. Reconstitution of B-lineage development in MBS-treated BtkTec ${ }^{-/}$mice. BM, splenocytes, peripheral blood, and peritoneal cells were harvested from $\mathrm{BtkTec}^{-1-}$ recipient mice 3 to 5 months after transplantation, evaluated by flow cytometry, and characterized based on "Hardy Fraction" stages of B-cell development. (A) BM (harvested 21 weeks after transplantation) was stained for B220, CD43, and lgM. Levels of Fractions A to C (pro-B) and Fraction D (pre-B), presented as percentages of the $\mathrm{B}^{2} 20^{+} \mathrm{B}$-cell compartment, are shown in the upper panel (CD43/B220, gated on $\mathrm{IgM}^{-}$cells). Fractions E to $\mathrm{F}$ (immature B, mature B) are shown in the lower panel (IgM+/B220, gated on live cells as determined by forward and side scatter profiles), and also as percentages of B220 ${ }^{+}$cells. (B) Splenocytes (harvested 15 weeks after transplantation) were stained for B220, IgM, and lgD. B220 cells, shown as percentages of total splenocytes, are shown in the upper panel (IgM/B220, gated on live cells). Late-stage splenic B-cell

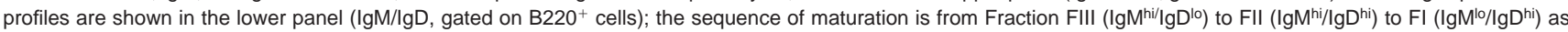
percentages of B220 $\mathrm{B}$ cells. (C) Peripheral blood (collected 21 weeks after transplantation) was analyzed by the same parameters as for splenocytes. (D) Representative plots of peritoneal cells collected from BtkTec ${ }^{-/-}$transplant recipients 21 weeks after transplantation and stained for lgM, Mac1, and CD5 are shown. Total B1 cells are shown in the upper panel (IgM/Mac1, gated on live cells); percentages are relative to total peritoneal cells. Further resolution into $\mathrm{CD}^{+} \mathrm{B} 1 \mathrm{a}$ and $\mathrm{CD}^{-} \mathrm{B} 1 \mathrm{~b}$, also presented as a percentage of the total peritoneal population, is shown in the lower panel (CD5/Mac1, gated on IgM ${ }^{-}$cells). Representative data from 2 of 3 independent experiments are shown.

development in Btk-deficient mice occurs in the spleen between Fraction F2 and F1 (Figure 3B). In the BtkTec ${ }^{-1-}$ recipient, F1 cells comprised $5 \%$ of the $\mathrm{B} 220^{+}$cells versus $39 \%$ in the WT control. In comparison, $47 \%$ of the splenic B cells in the MBS-treated recipient were F1 cells. A similar trend was seen in peripheral blood (Figure 3C).

Another feature of Btk-deficient strains is the complete loss of peritoneal B1 B cells. This population is identified by the coexpression of IgM and Mac1 (CD11b), and can be further separated into $\mathrm{CD}^{+} \mathrm{B} 1 \mathrm{a}$, and $\mathrm{CD}^{-} \mathrm{B} 1 \mathrm{~b} \mathrm{~B}$ cells. To determine if $\mathrm{B} 1$ cells were restored, peritoneal cells were isolated and evaluated (Figure 3D). $\mathrm{IgM}^{+} / \mathrm{Mac}^{+} \mathrm{B} 1$ cells constitute less than $3 \%$ of the total peritoneal population in a $\mathrm{BtkTec}^{-1-}$ recipient as compared with $38 \%$ in the WT control. This population was clearly restored in the MBStreated animal, comprising $18 \%$ of the total peritoneal cells in the example shown. Moreover, $\mathrm{CD}^{+} \mathrm{B} 1 \mathrm{a}$ cells were increased from $1 \%$ in the $\mathrm{BtkTec}^{-1-}$ control to $10 \%$ in the MBS animal, as compared with $22 \%$ in the WT control. These results demonstrate that peritoneal B1 cells can be reconstituted following MBS transduction.

Absolute cell numbers of each B-lineage developmental subset were calculated using the flow cytometry percentages and total cell counts. Figure 4 provides a summary of these data from the 4 experiments. Analysis of BM revealed significant recovery of total $\mathrm{B}$-lineage cellularity in MBS-treated mice as compared with either mock-transduced (Figure 4Ai) or MIG-transduced (Figure 4Bi) $\mathrm{BtkTec}^{-1-}$ control cells. Although the numbers of cells in the pro-B fraction (Fractions A-C) were slightly higher than in WT mice that underwent transplantation, there was a substantial increase in the immature and mature B fractions (Fractions E-F) with restoration to normal cell numbers in the majority of MBS recipients. Striking evidence for MBS-mediated restoration of peripheral B-cell development was also observed in the spleen (Figure 4Aii, Bii). Fraction
F1, mature splenic B-cell numbers were fully rescued in many animals and were at least $30 \%$ to $50 \%$ of normal in all MBS recipients. Peritoneal B-cell numbers (Figure 4Aiii) were also restored in experiments where this was evaluated.

Taken together, our data indicate that MBS retroviral gene transfer is capable of restoring both the early and the late developmental blocks associated with the $\mathrm{BtkTec}^{-1-}$ phenotype.

\section{MBS transduction restores immunoglobulin levels and TI-II immune responses in $\mathrm{BtkTec}^{-/-}$mice}

Low serum levels of $\operatorname{IgM}$ and $\mathrm{IgG}_{3}$ and failure to respond to T-independent, type 2 (TI-II) antigens are fundamental functional defects present in all Btk-deficient strains..$^{25,27,34}$ Kinetic analysis from a representative experiment (Figure 5A) demonstrates the progressive increase in serum $\operatorname{IgM}$ and $\mathrm{IgG}_{3}$ to normal levels within approximately 8 weeks in MBS-treated animals (versus $\sim 4-6$ weeks in control recipients). Similar results were observed in all experiments (Figure 5B). This kinetic correlated with the progressive increase in $\mathrm{Btk}^{+}$mature $\mathrm{B}$ cells observed over the same period. Notably, recipients of $10 \%$ chimeric cell mixtures exhibited serum Ig concentrations similar to the MBS-transduced and WT animals despite a distinctly less robust cellular reconstitution (Figure 4). This latter observation suggests that small numbers of Btkexpressing cells may be sufficient to maintain circulating IgM and $\mathrm{IgG}_{3}$ levels and/or that "natural antibody" production is additionally down-regulated in animals with normal numbers of mature B cells.

To ascertain whether MBS transduction could rescue Tindependent immune responses, mice were immunized with the TI-II antigen TNP-Ficoll. Strikingly, MBS-treated mice responded with production of normal levels of TNP-specific IgM and $\mathrm{IgG}_{3}$ (Figure 5A-B) antibodies. A slow decline in TNP-specific IgM was 
A

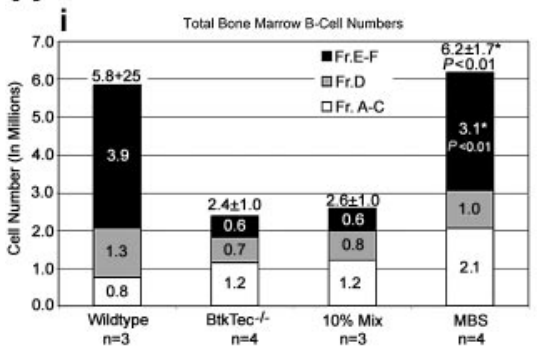

ii
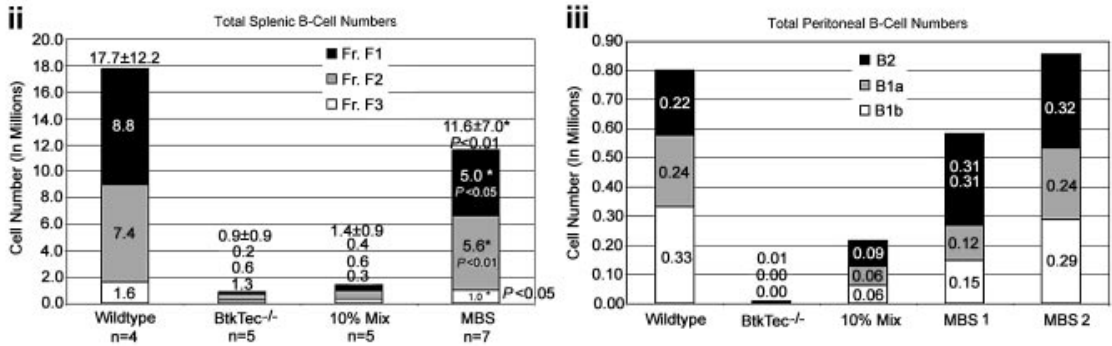

B

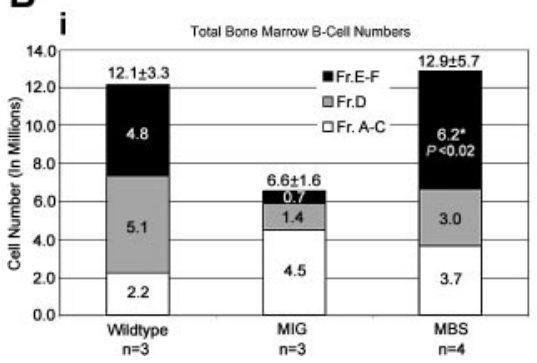

ii

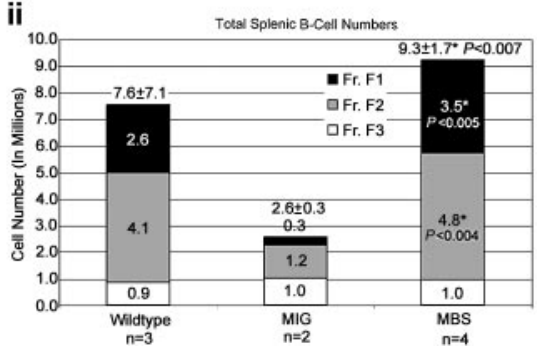

Figure 4. Reconstitution of B-cell numbers in MBS-treated mice. Total numbers for B-cell subsets, based on the developmental schema of Li and colleagues, ${ }^{48}$ were calculated using flow cytometry percentages and total cell counts. (Ai-ii) Combined results for BM and spleen, respectively, from experiments 1 to 3 . (Aiii) Peritoneal B-lineage analysis was performed for 1 experiment, and the results from 1 animal from each control category and 2 MBS-treated animals are shown. MBS-treated mice exhibited

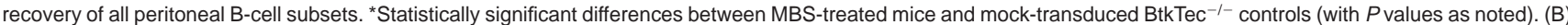
Analysis of BM and spleen B-cell subsets from animals reconstituted with MBS- versus MIG-transduced stem cells. The numbers for each B-cell subset are shown, and mean total B-cell numbers with SEM are included at the top of each bar. *Statistically significant differences between MBS-treated mice and MIG-treated animals (with $P$ values as noted).

observed in both MBS-transduced and WT control recipients over time (Figure 5A). This correlated with increasing titers of TNPspecific $\mathrm{IgG}_{3}$, consistent with isotype switch to $\mathrm{IgG}_{3}$ in response to repeated immunization. ${ }^{49}$ Rescue of the T-independent immune response was observed in all experiments (Figure 5B). These results are in contrast to our previous studies with a Btk transgenic mouse that expressed subendogenous levels of Btk (Btk ${ }^{\mathrm{lo}}$ mice). Despite restoration of mature follicular B-cell numbers and IgM and $\mathrm{IgG}_{3}$ levels, Btk ${ }^{\mathrm{lo}}$ mice fail to respond to TI-II antigen stimulation. ${ }^{50}$ These observations indicate that retroviral-mediated Btk gene delivery is capable of rescuing a stringent, Btk dosedependent functional response.

\section{MBS transduction rescues BCR- and mitogen-dependent $\mathrm{B}$-cell proliferative responses in $\mathrm{BtkTec}^{-1-}$ mice}

To further investigate the degree of functional rescue in the MBS-treated mice, we tested splenocytes from animals that had undergone transplantation for response to B-cell mitogens or BCR engagement (Figure 5C). While untreated BtkTec ${ }^{-1-}$-derived cells responded to control stimulation with phorbol ester and ionomycin, ${ }^{3} \mathrm{H}$-thymidine incorporation was reduced in response to LPS stimulation and absent with IgM crosslinking. In contrast, both the LPS and anti-IgM dependent responses in splenocytes derived from the MBS-treated mice were significantly restored in MBStreated animals. BCR-dependent proliferative responses were restored in all MBS-treated recipients within 13 to 21 weeks in 4 independent experiments (Figure 5C; and data not shown).

Splenocytes and BM from all Btk-deficient strains fail to generate B-lineage colonies when placed in an agar-based, mitogenic colony-forming assay (CFU-B assay).$^{51}$ In all cohorts, cells from control $\mathrm{BtkTec}^{-1-}$ mice that underwent transplantation produced few or no colonies (Figure 6). In contrast, both BM (Figure 6A) and splenocytes (Figure 6B) from MBS-treated recipients formed abundant agar colonies. While colony numbers were somewhat variable between individual recipients, the average colony number in MBS-treated mice reached $50 \%$ to $100 \%$ of the numbers derived from recipients of WT marrow. B-cell colony size was also equivalent in WT and MBS-treated mice (data not shown). Colony numbers in MBS-treated mice were also higher than in the $10 \%$ chimeric cell mixture-derived cell populations; or in cells derived from MIG-transduced stem cells.

Taken together, these results demonstrate MBS gene transfer can correct key functional and developmental defects present in $\mathrm{BtkTec}^{-1-}$ mice.

\section{Long-term correcting hematopoietic stem cells are transduced by MBS}

Sustained Btk expression in BM, spleen, and peripheral blood was observed for more than 24 weeks in MBS-transduced BM recipients. Production of newly formed $\operatorname{IgM}^{+}$immature B cells was also maintained throughout this period. This strongly suggests that the phenotypic rescue resulted from the transduction of early hematopoietic stem cells capable of self-renewal. To directly evaluate this question, BM from primary transplant recipients was transferred into $\mathrm{BtkTec}^{-1-}$ secondary recipient hosts. At 6 weeks after transplantation, peripheral blood analysis revealed mature circulating B cells in mice that underwent transplantation with BM from MBS primary recipients. In all 3 experimental MBS-transduced cohorts, the percentage of B cells in the peripheral blood was similar to, or slightly less than, the WT control secondary recipients. In contrast, mature $\mathrm{B}$ cells were absent in secondary recipients of $\mathrm{BtkTec}^{-1-}$ marrow (Figure 7A). In the example shown, the percentage of peripheral blood B cells in the MBS secondary recipients (4\%) was lower than the WT control recipient $(8 \%)$, but significantly higher than the $\mathrm{BtkTec}^{-/-}$secondary recipients (1\%) and recipients of the $10 \%$ chimeric cell mixture 
A
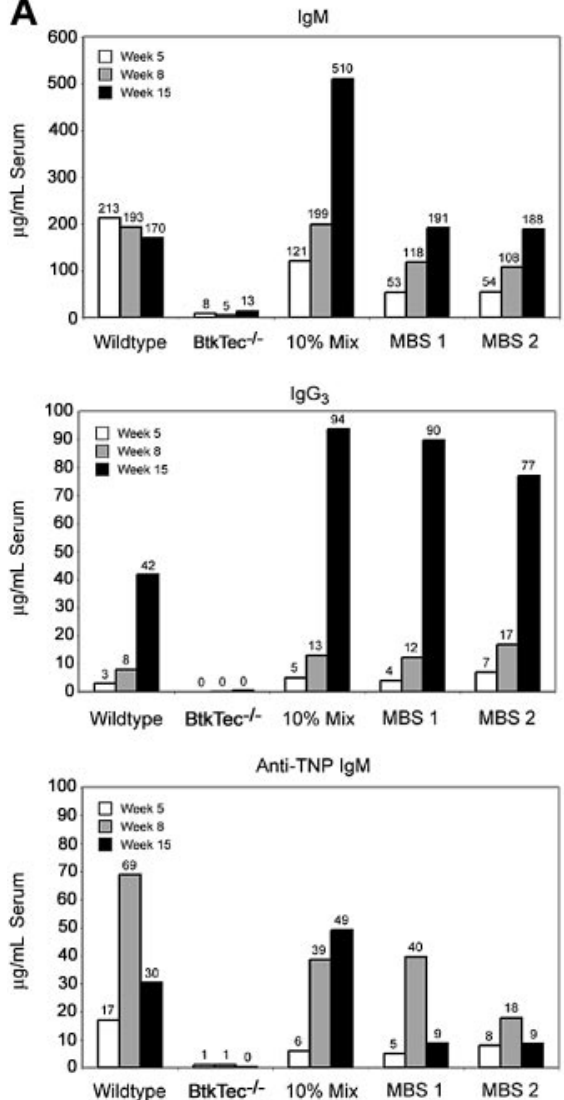

B
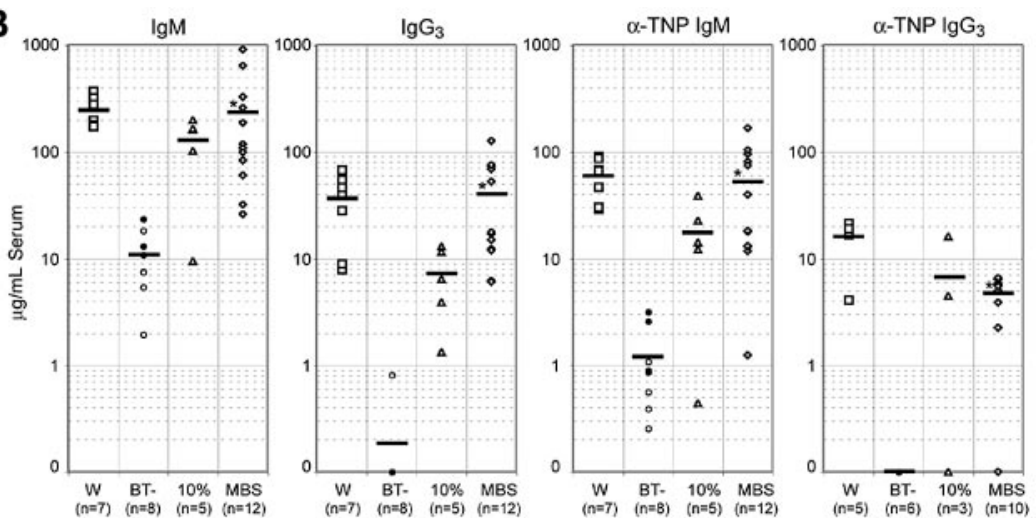

C

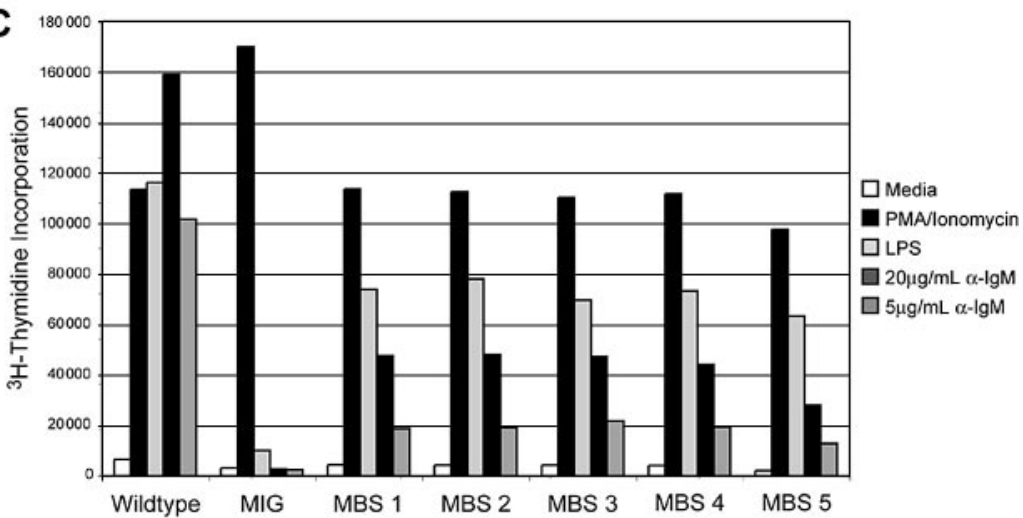

Figure 5. Rescue of serum Ig levels, TI-II responses, and BCR-dependent proliferative responses in MBS-treated BtkTec ${ }^{-/-}$mice. Engrafted recipients were immunized with TNP-Ficoll, bled, and analyzed for serum IgM, IgG $\mathrm{G}_{3}$ and anti-TNP-specific IgM levels. (A) Kinetic data from individual animals in a representative experiment shows restoration of antibody production and TI-II levels by about 15 weeks after transplantation with MBS-transduced bone marrow cells. (B) IgM, IgG ${ }_{3}$, and anti-TNP IgM results from all experiments, analyzed between weeks 7 and 14 after transplantation, show significant improvement in MBS-treated animals versus BtkTec ${ }^{-1-}$ controls. *Statistical significance, $P<.01$ for $\operatorname{lgM}$, IgG ${ }_{3}$, and anti-TNP IgM. Anti-TNP IgG levels from weeks 13 to 21 are also shown $(P<.0001)$. Mean serum antibody levels are indicated by a horizontal bar. Open versus closed circles denote results for mock- versus MIG-transduced BtkTec ${ }^{-1-}$ animals, respectively. (C) Total splenocytes were harvested after transplantation, red blood cells lysed, and cultured with media alone (negative control), phorbol ester and ionomycin (positive control), LPS, or 2 doses of anti-IgM F $(\mathrm{ab})_{2}$ antibody. Proliferative responses were measured by ${ }^{3} \mathrm{H}$-thymidine uptake. Results from a representative experiment (experiment 4 ) demonstrate restoration of LPS and anti-IgM responses in MBS-treated animals $(P<.001$ for MBS- versus MIG-treated animals for all stimuli). Analysis of data from experiments 1 to 3 also demonstrated statistically significant differences between MBS-treated mice $(\mathrm{n}=7)$ and BtkTec ${ }^{-1-}$ control mice $(\mathrm{n}=5 ; P<.01$ for $20 \mu \mathrm{g}$ and $P<.05$ for $5 \mu \mathrm{g}$ anti-IgM stimulation).

A

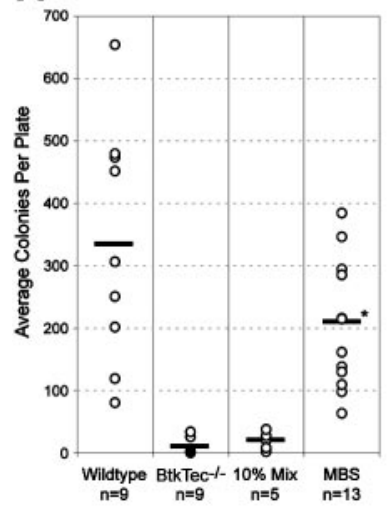

B

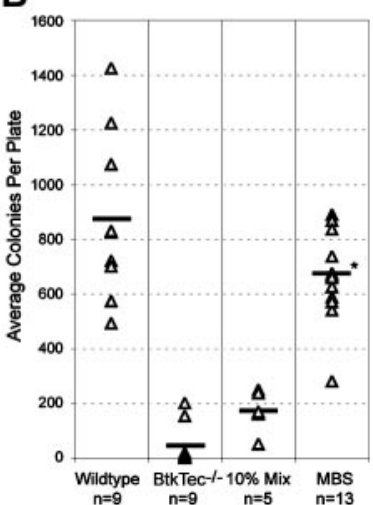

Figure 6. Rescue of CFU-B colony formation in MBS-treated BtkTec ${ }^{-/-}$mice. BM (A) and splenocytes (B) from individual animals were cultured with LPS and sheep red blood cells (SRBCs) in agar to induce B-cell colony formation. Colonies were enumerated at day 7 and data from all experimental cohorts are represented. The colony count for each animal (average of 2 plates) is shown and the mean for all animals in each experimental category is indicated by a bar. *Statistical difference between MBS-treated mice and mock-transduced (open symbols) or MIGtransduced (filled symbols) BtkTec ${ }^{-/-}$controls $(P<.00005)$.

(1\%). This difference was most apparent with regard to the relative number of mature Fraction FI B cells. In the MBS secondary host, FI cells comprised $22 \%$ of circulating B cells compared with $32 \%$ in the WT control, $6 \%$ in the $\mathrm{BtkTec}^{-1-}$ control, and $2 \%$ in chimeric mixture recipient, respectively. We also evaluated B-cell functional activity by analyzing immunoglobulin levels and TI-II responses (Figure 7B). These data demonstrate sustained rescue of these Btk-mediated functional responses. The relatively lower B-cell numbers and less robust developmental rescue observed in both control and MBS-treated secondary recipient mice are consistent with previous studies that report diminished reconstitution capacity with serial transplantation. ${ }^{52}$ Together, these observations demonstrate that transduction of stem cells leads to sustained rescue of Btk-dependent B-cell development and function.

\section{Discussion}

Using the BtkTec ${ }^{-1-}$ double-knockout mouse as a model of XLA, we have tested whether Btk retroviral gene therapy could correct the BtkTec ${ }^{-/-}$phenotype. Analysis of B cells in the BM, spleen, peripheral blood, and peritoneum of engrafted mice demonstrates 
A

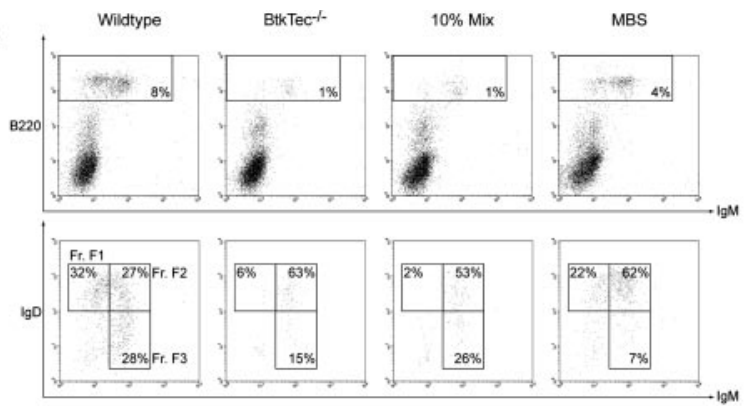

B

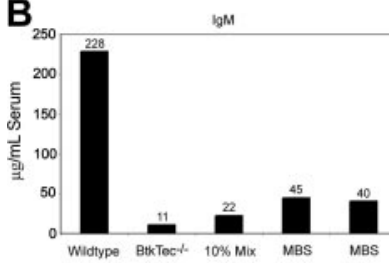

Ant-TNP IgM
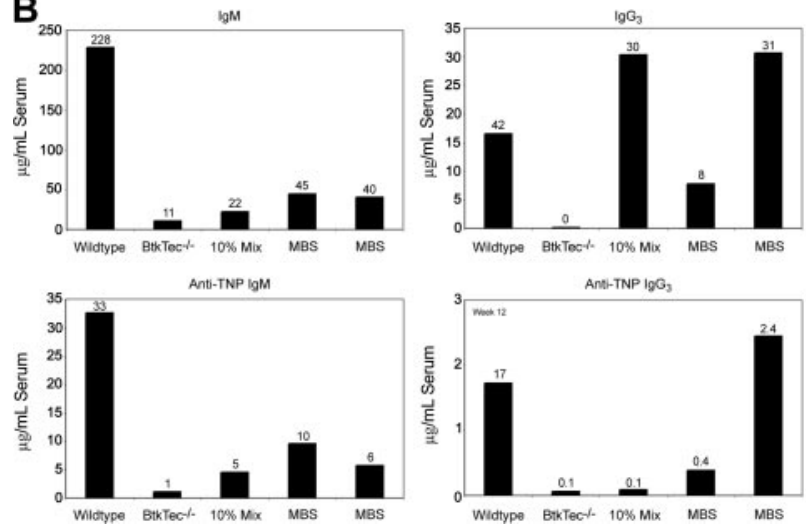

Ant-TNP IgG,

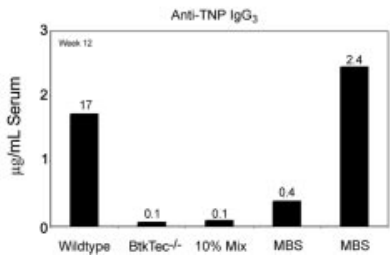

Figure 7. Analysis of B-lineage development in recipients of a secondary transplant. Representative data from 1 of 3 experiments showing the following (A) Peripheral blood collected from recipients of a secondary transplant 6 weeks after transplantation and stained for B220, IgM, and lgD. B220 ${ }^{+}$cells, presented as percentages of total peripheral blood mononuclear cells, are shown in the upper panel (IgM/B220, gated on live cells). Fraction $F$ subsets, presented as percentages of total $\mathrm{B}^{2} 20^{+}$B cells, are shown in the lower panel. (B) Serum $\operatorname{lgM}, \lg _{3}$, and TNP-specific lgM for TNP-immunized, individual, recipients of a secondary transplant from the same experiment. TNP-specific $\lg \mathrm{G}_{3}$ from week 12 is also shown. Combined data from all 3 experiments demonstrated a statistically significant increase in the total number of $\operatorname{lgM}^{+} / \mathrm{B}_{2} 20^{+} \mathrm{B}$ cells in MBS-treated mice $(P<.01)$. These data suggest that Btk-dependent B-cell development and function are preserved in secondary MBS recipients.

that transduction of 5FU-treated BM with the MBS vector can lead to stable expression of exogenous Btk without obvious detrimental effects. Our findings also demonstrate that retroviral-mediated expression of human Btk is sufficient to alleviate both the early and late developmental blocks associated with Btk deficiency in mice. This is evident by the significant increases in both relative population size and absolute cell numbers of increasingly mature B-cell developmental subsets: Hardy Fractions D, E, and F (pre-B and onward) in the $\mathrm{BM}$, and FI (follicular mature $\operatorname{Ig} \mathrm{M}^{\mathrm{lo}} / \mathrm{IgD}^{\text {hi }} \mathrm{B}$ cells) in the spleen and periphery. Both $\mathrm{CD}^{+}$and $\mathrm{CD} 5^{-}$peritoneal $\mathrm{B} 1$ cells were also reestablished, demonstrating transduction of a BM precursor for these unique developmental subsets. Most notably, MBS treatment also led to restoration of normal mature B-cell function, as illustrated by the normalized serum IgM and $\mathrm{IgG}_{3}$, response to immunization with TI-II antigens, and the proliferative response to $\mathrm{BCR}$ engagement. Restoration of these key outcomes represents a highly stringent measure of physiologically relevant levels of Btk enzymatic activity. The progressive accumulation of TNP-specific $\mathrm{IgG}_{3}$ also suggests that corrected cells can undergo isotype switching.

The data presented also provide clear evidence supporting the predicted selective advantage in B-lineage cells linked to the presence of the therapeutic gene. This was demonstrated by the selective accumulation of transgene-expressing B cells, enrichment for higher viral copy number specifically within B-lineage cells, and the progressive increase in immune function over time. Finally, the results of the secondary transplant studies, in association with the demonstration of sustained Btk expression, strongly support the conclusion that these events were mediated by transduction of early hematopoietic progenitors with self-renewal capacity. Taken together, these data indicate that MBS-mediated stem cell gene transfer supports a broad constellation of complex, Btk-dependent, functional, and developmental B-cell activities.

The results of the current study are in distinct contrast to those observed in Xid or Btk ${ }^{-l-}$ single knockout murine models (Yu et $\mathrm{al}^{53,54}$; and data not shown). We carried out extensive previous studies using alternative Btk-ires-GFP retroviral vectors and transplantation of transduced Xid or Btk ${ }^{-1-} 5 \mathrm{FU}-$ treated BM cells into severe combined immunodeficient (SCID) or Btk-deficient recipients. Sustained GFP expression was observed in peripheral B cells for more than 1 year using either an MSCV-based vector or an alternative vector, MND, designed to facilitate viral expression in hematopoietic cells. ${ }^{55}$ However, this approach led to a relatively limited selective advantage for GFP-expressing B cells and only partial restoration of mature $\operatorname{IgM}^{\mathrm{lo}} \operatorname{IgD}^{\text {hi }} \mathrm{B}$-cell numbers and serum IgM and $\mathrm{IgG}_{3}$ levels. TI-II and BCR-dependent responses were not rescued at any time point ( 4 weeks to 1.5 years after transplantation). Other groups have recently reported similar preliminary observations in Xid mice. ${ }^{36,56}$

Several important factors may have contributed to the functional rescue in the BtkTec ${ }^{-/-}$model. First, the crucial role for Btk at the pre-B-cell transition most likely increased the relative survival and clonal expansion of $\mathrm{Btk}^{+}$pre-B cells. Xid and $\mathrm{Btk}^{-1-}$ mice (that express Tec) exhibit nearly normal early B-lineage development and do not experience a similar selective advantage. Second, amplification of $\mathrm{Btk}^{+}$pre-B cells likely increased the number of gene-expressing cells that subsequently completed light chain rearrangement and entered the periphery. This may limit the impact of the approximately $90 \%$ cell loss operative at the immature stage. In contrast, in Xid or Btk ${ }^{-1-}$ mice, this loss and the lack of an early selective advantage may have led to numbers of Btk-expressing immature cells that were below the threshold required for functional reconstitution. ${ }^{39}$ Third, despite high initial transduction and expression, a combination of factors, including silencing, variegation, or other positional effects associated with exit from cell cycle and/or cell differentiation, led to progressive diminution of retroviral long-terminal repeat-mediated expression in mature B lymphocytes in Xid and Btk ${ }^{-1-}$ mice..$^{57,58}$ The strong selective pressure in the $\mathrm{BtkTec}^{-1-}$ model, operative at more than one developmental checkpoint, probably helped to counter these cumulative events. Finally, differences in vector design including use of the SAR element, human Btk, and elimination of cis-linked GFP may also have played a role in mediating a higher sustained level of Btk expression in the current studies.

Our findings in the BtkTec ${ }^{-/-}$model constitute strong support for the development of an analogous gene therapy approach in human XLA. Based on these findings, we predict that retroviralmediated Btk gene transfer could provide a significant advantage over the current supportive therapy for XLA. Recent studies in genetically defined XLA patients indicate that infectious and noninfectious morbidity remains high, and mortality rates can reach $30 \%$ over 10 years despite comprehensive care. ${ }^{59,60}$ The milder disease phenotype in XLA patients with partial Btk activity suggests that even partial restoration of enzymatic activity may lead to clinical benefit. ${ }^{61,62}$ When compared with other candidate immunodeficiency disorders where gene therapy is being pursued, XLA exhibits some potential strategic advantages. XLA is the most 
common immunodeficiency with a selective advantage for genecorrected lymphoid cells, and XLA patients comprise the largest available cohort for evaluation of such a therapy. Because the level of circulating immunoglobulin has no effect on Btk-dependent selection, gene therapy could be administered without discontinuing conventional therapy. This distinguishes XLA, for example, from the confounding effects of polyethylene glycol-modified adenosine deamirase (PEG-ADA) therapy in SCID. ${ }^{63}$ Autologous stem cell gene therapy for XLA may prove to be more efficient than matched allogeneic stem cell transplantation, which has not provided clinical benefit to date in the absence of BM conditioning. ${ }^{64}$ Finally, the relatively more stable condition of XLA patients (in comparison with SCID) will permit extended evaluation as well as additional optimization of this therapeutic approach.

At least 2 key questions with regard to the efficacy of Btk gene therapy in the $\mathrm{BtkTec}^{-1-}$ model remain to be addressed. First, nontoxic or minimally toxic conditioning is crucial for clinical application. Our preliminary data indicate that relatively small numbers of BM cells can restore immune function in nonmyeloablated $\mathrm{BtkTec}^{-1-}$ mice. Determining whether the selective advantage of Btk-corrected cells is sufficient to restore function in a nonmyeloablated setting is a current priority. Second, it remains to be determined whether Btk gene therapy will restore protective response to infectious challenge. Response of MBS-treated mice to $S$ pneumoniae bacteremia is being used to address this question.

This study failed to identify evidence for toxicity related to constitutive Btk expression in marrow-derived cell populations in either primary or secondary recipients. Our results also suggest that regulated expression of $\mathrm{Btk}$ is not essential for therapeutic rescue. Although Btk is a potent mediator of B-cell activation and proliferation, previous studies indicate that even very high levels of transgenic expression (10-fold endogenous) have no obvious deleterious effects. ${ }^{65}$ In addition, overexpression of activated, mutant Btk leads only to the reduced survival of immature B cells via enhanced negative selection. ${ }^{66}$ While these findings suggest that Btk gene transfer is safe, additional experiments with larger numbers of mice and with human systems are required to address this issue.

Our results demonstrate the feasibility of Btk gene therapy and constitute an encouraging first step toward gene therapy for human XLA. The gene transfer and transplantation model we have described provides a valuable approach for the analysis of alternative vectors and for structure/function studies of Btk and other key proteins in the pre-BCR and BCR signaling pathways

\section{Acknowledgments}

We wish to thank the following individuals: Vicky Dang, Maria Garcia-Lloret, Rafael Hernandez, Jimmy Johnson, Socheath Khim, Erick Lansigan, Datian Lin, Enca Montecito-Rodriquez, Karen Sommer, and Matt Wahl for technical assistance; Tony Blau and Ken Dorshkind for critical reading of the manuscript; and members of the Rawlings and Dorshkind laboratories for thoughtful discussions, support, and technical advice.

\section{References}

1. Bruton $O$. Agammaglobulinemia. Pediatrics. 1952;9:722-728.

2. Lederman HM, Winkelstein JA. X-linked agammaglobulinemia: an analysis of 96 patients. Medicine (Baltimore). 1985;64:145-156.

3. Hermaszewski RA, Webster AD. Primary hypogammaglobulinaemia: a survey of clinical manifestations and complications. Q J Med. 1993;86: 31-42.

4. Liese JG, Wintergerst U, Tympner KD, Belohradsky $\mathrm{BH}$. High- vs low-dose immunoglobulin therapy in the long-term treatment of X-linked agammaglobulinemia. Am J Dis Child. 1992;146: 335-339.

5. Conley ME. X-linked immunodeficiencies. Curr Opin Genet Dev. 1994;4:401-406.

6. Thomas JD, Sideras P, Smith Cl, Vorechovsky I, Chapman V, Paul WE. Colocalization of X-linked agammaglobulinemia and $\mathrm{X}$-linked immunodeficiency genes. Science. 1993;261:355-358.

7. Vetrie D, Vorechovsky I, Sideras P, et al. The gene involved in X-linked agammaglobulinaemia is a member of the src family of protein-tyrosine kinases. Nature. 1993;361:226-233.

8. Ochs HD, Smith $\mathrm{Cl}$. X-linked agammaglobulinemia: a clinical and molecular analysis. Medicine (Baltimore). 1996;75:287-299.

9. Smith $\mathrm{Cl}$, Islam TC, Mattsson PT, Mohamed AJ, Nore BF, Vihinen M. The Tec family of cytoplasmic tyrosine kinases: mammalian Btk, Bmx, Itk, Tec, Txk and homologs in other species. Bioessays. $2001 ; 23: 436-446$.

10. Mano $\mathrm{H}$. The Tec family protein-tyrosine kinases: a subset of kinases for a subset of signalings. Int J Hematol. 1999;69:6-12.

11. Rawlings DJ, Witte ON. The Btk subfamily of cytoplasmic tyrosine kinases: structure, regulation and function. Semin Immunol. 1995;7:237-246.

12. Tsukada S, Saffran DC, Rawlings DJ, et al. Deficient expression of a B cell cytoplasmic tyrosine kinase in human $\mathrm{X}$-linked agammaglobulinemia. Cell. 1993;72:279-290.

13. de Weers M, Verschuren MC, Kraakman ME, et al. The Bruton's tyrosine kinase gene is expressed throughout $B$ cell differentiation, from early precursor B cell stages preceding immunoglobulin gene rearrangement up to mature $\mathrm{B}$ cell stages. Eur J Immunol. 1993;23:3109-3114.

14. Pawson T. Protein modules and signalling networks. Nature. 1995;373:573-580.

15. Vihinen M, Brandau O, Branden LJ, et al. BTK base, mutation database for X-linked agammaglobulinemia (XLA). Nucleic Acids Res. 1998;26: 242-247.

16. Campana D, Farrant J, Inamdar N, Webster AD, Janossy $G$. Phenotypic features and proliferative activity of $B$ cell progenitors in X-linked agammaglobulinemia. J Immunol. 1990;145:1675-1680.

17. Nomura K, Kanegane H, Karasuyama H, et al. Genetic defect in human X-linked agammaglobulinemia impedes a maturational evolution of pro-B cells into a later stage of pre-B cells in the B-cell differentiation pathway. Blood. 2000;96:610-617.

18. Noordzij JG, de Bruin-Versteeg S, Comans-Bitte WM, et al. Composition of precursor B-cell compartment in bone marrow from patients with $\mathrm{X}$ linked agammaglobulinemia compared with healthy children. Pediatr Res. 2002;51:159-168.

19. Pearl ER, Vogler LB, Okos AJ, Crist WM, Lawton AR 3rd, Cooper MD. B lymphocyte precursors in human bone marrow: an analysis of normal individuals and patients with antibody-deficiency states. J Immunol. 1978;120:1169-1175.

20. Good RA. Studies on agammaglobulinemia, II: failure of plasma cell formation in the bone marrow and lymph nodes of patients with agammaglobulinemia. J Lab Clin Med. 1955;46:167-181.

21. Karasuyama H, Rolink A, Melchers F. Surrogate light chain in B cell development. Adv Immunol. 1996;63:1-41.

22. Guo B, Kato RM, Garcia-Lloret M, Wahl MI, Rawl- ings DJ. Engagement of the human pre-B cell receptor generates a lipid raft-dependent calcium signaling complex. Immunity. 2000;13:243-253.

23. Rawlings DJ, Saffran DC, Tsukada S, et al. Mutation of unique region of Bruton's tyrosine kinase in immunodeficient XID mice. Science. 1993;261: 358-361.

24. Scharenberg AM, El-Hillal O, Fruman DA, et al. Phosphatidylinositol-3,4,5-trisphosphate (Ptdlns 3,4,5-P3)/Tec kinase-dependent calcium signaling pathway: a target for SHIP-mediated inhibitory signals. EMBO J. 1998;17:1961-1972.

25. Wicker LS, Scher I. X-linked immune deficiency (xid) of CBA/N mice. Curr Top Microbiol Immunol. 1986; 124:87-101.

26. Scher I. CBA/N immune defective mice: evidence for the failure of a B cell subpopulation to be expressed. Immunol Rev. 1982;64:117-136.

27. Khan WN, Alt FW, Gerstein RM, et al. Defective B cell development and function in Btk-deficient mice. Immunity. 1995;3:283-299.

28. Kerner JD, Appleby MW, Mohr RN, et al. Impaired expansion of mouse $B$ cell progenitors lacking Btk. Immunity. 1995;3:301-312.

29. Loder F, Mutschler B, Ray RJ, et al. B cell development in the spleen takes place in discrete steps and is determined by the quality of $B$ cell receptor-derived signals. J Exp Med. 1999;190: 75-89.

30. Su TT, Rawlings DJ. Transitional B lymphocyte subsets operate as distinct checkpoints in murine splenic B cell development. J Immunol. 2002;168: 2101-2110.

31. Kurosaki T, Tsukada S. BLNK: connecting Syk and Btk to calcium signals. Immunity. 2000;12 1-5.

32. Rawlings DJ. Bruton's tyrosine kinase controls a sustained calcium signal essential for B lineage development and function. Clin Immunol. 1999; 91:243-253. 
33. Fluckiger AC, Li Z, Kato RM, et al. Btk/Tec kinases regulate sustained increases in intracellular $\mathrm{Ca} 2+$ following B-cell receptor activation. EMBO J. 1998;17:1973-1985.

34. Ellmeier W, Jung S, Sunshine MJ, et al. Severe B cell deficiency in mice lacking the tec kinase fam ily members Tec and Btk. J Exp Med. 2000;192: 1611-1624.

35. Tomlinson MG, Kurosaki T, Berson AE, Fujii GH Johnston JA, Bolen JB. Reconstitution of Btk sig naling by the atypical tec family tyrosine kinases Bmx and Txk. J Biol Chem. 1999;274:13577 13585.

36. Conley ME, Rohrer J, Rapalus L, Boylin EC, Minegishi Y. Defects in early B-cell development: comparing the consequences of abnormalities in pre-BCR signaling in the human and the mouse. Immunol Rev. 2000;178:75-90.

37. Conley ME, Puck JM. Definition of the gene loci in X-linked immunodeficiencies. Immunol Invest. 1988;17:425-463.

38. Sprent $\mathrm{J}$, Bruce J. Physiology of B cells in mice with X-linked immunodeficiency (xid), III: disappearance of xid $B$ cells in double bone marrow chimeras. J Exp Med. 1984;160:711-723.

39. Rohrer J, Conley ME. Correction of X-linked immunodeficient mice by competitive reconstitution with limiting numbers of normal bone marrow cells. Blood. 1999;94:3358-3365.

40. Porpiglia AS, Rohrer J, Conley ME. Reconstitution of $B$ cell function in murine models of immunodeficiency. Clin Immunol. 2003;107:90-97.

41. Quan ZS, Dick RF, Regueiro B, Quintans J. B cell heterogeneity, II: transplantation resistance in xid mice which affects the ontogeny of B cell subpopulations. Eur J Immunol. 1981;11:643-649.

42. Quintans J. The immune response of CBA/N mice and their $\mathrm{F} 1$ hybrids to 2,4,6-trinitrophenylated (TNP) antigens, I: analysis of the response to TNP-coupled lipopolysaccharide in vivo and at the clonal level. Eur J Immunol. 1979:9:67-71.

43. Hawley RG, Lieu FH, Fong AZ, Hawley TS. Versatile retroviral vectors for potential use in gene therapy. Gene Ther. 1994;1:136-138.

44. Murray L, Travis M, Luens-Abitorabi K, et al. Addition of the human interferon beta scaffold attachment region to retroviral vector backbones increases the level of in vivo transgene expression among progeny of engrafted human hematopoietic stem cells. Hum Gene Ther. 2000;11:20392050.

45. Kang SW, Wahl MI, Chu J, et al. PKCbeta modu lates antigen receptor signaling via regulation of Btk membrane localization. EMBO J. 2001;20: 5692-5702.

46. Naviaux RK, Costanzi E, Haas M, Verma IM. The pCL vector system: rapid production of helperfree, high-titer, recombinant retroviruses. J Virol. 1996;70:5701-5705

47. Pfaffl MW. A new mathematical model for relative quantification in real-time RT-PCR. Nucleic Acids Res. 2001;29:e45.

48. Li YS, Hayakawa K, Hardy RR. The regulated expression of $\mathrm{B}$ lineage associated genes during $B$ cell differentiation in bone marrow and fetal liver. J Exp Med. 1993;178:951-960.

49. Le Moal MA, Colle JH, Truffa-Bachi P. Study on B-memory generation by Tnp-Ficoll: induction but not expression is observed among various inbred mouse strains. Cell Immunol. 1984;87:110-117.

50. Satterthwaite $A B$, Cheroutre $H$, Khan WN, Sideras $\mathrm{P}$, Witte ON. Btk dosage determines sensitivity to $B$ cell antigen receptor cross-linking. Proc Natl Acad Sci U S A. 1997;94:13152-13157.

51. Dorshkind K, Phillips RA. Characterization of early $B$ lymphocyte precursors present in longterm bone marrow cultures. J Immunol. 1983; $131: 2240-2245$

52. Mauch P, Hellman S. Loss of hematopoietic stem cell self-renewal after bone marrow transplantation. Blood. 1989;74:872-875.

53. Yu P, Tabuchi R, Kato RM, et al. Correction of Xlinked immunodeficiency by retroviral mediated transfer of Bruton's tyrosine kinase [abstract]. Blood. 2000;100:210a.

54. Yu PW, Tabuchi R, Kato RM, et al. Reconstitution of Bruton's tyrosine kinase function in murine models of X-linked agammaglobulinemia [abstract]. Mol Ther. 2002;5:S22-S23.

55. Robbins PB, Skelton DC, Yu XJ, Halene S, Leonard EH, Kohn DB. Consistent, persistent expression from modified retroviral vectors in murine hematopoietic stem cells. Proc Natl Acad Sci U S A. 1998:95:10182-10187.

56. Tanabe H, Miyake K, Shimada T. HIV mediated expression of Bruton's tyrosine kinase in hemato- poietic stem cells promotes $\mathrm{B}$ cell development but not restore immunoglobulin production in $\mathrm{X}$ linked immunodeficient mice [abstract]. Mol Ther 2003;7:S410.

57. Hawley RG. Progress toward vector design for hematopoietic stem cell gene therapy. Curr Gene Ther. 2001;1:1-17.

58. Klug CA, Cheshier S, Weissman IL. Inactivation of a GFP retrovirus occurs at multiple levels in long-term repopulating stem cells and their differentiated progeny. Blood. 2000;96:894-901.

59. Plebani A, Soresina A, Rondelli R, et al. Clinical, immunological, and molecular analysis in a large cohort of patients with X-linked agammaglobulinemia: an Italian multicenter study. Clin Immunol. 2002;104:221-230.

60. Van der Hilst JC, Smits BW, van der Meer JW. Hypogammaglobulinaemia: cumulative experience in 49 patients in a tertiary care institution. Neth J Med. 2002;60:140-147.

61. Saffran DC, Parolini O, Fitch-Hilgenberg ME, et al. Brief report: a point mutation in the $\mathrm{SH} 2$ do main of Bruton's tyrosine kinase in atypical Xlinked agammaglobulinemia. N Engl J Med. 1994; 330:1488-1491

62. Kornfeld SJ, Haire RN, Strong SJ, et al. A novel mutation (Cys145 $\rightarrow$ Stop) in Bruton's tyrosine kinase is associated with newly diagnosed X-linked agammaglobulinemia in a 51-year-old male. Mol Med. 1996;2:619-623.

63. Kohn DB, Hershfield MS, Carbonaro D, et al. T lymphocytes with a normal ADA gene accumulate after transplantation of transduced autologous umbilical cord blood CD34 ${ }^{+}$cells in ADA-deficient SCID neonates. Nat Med. 1998;4:775-780.

64. Howard V, Myers LA, Williams DA, et al. Stem cell transplants for patients with X-linked agammaglobulinemia. Clin Immunol. 2003;107:98-102.

65. Maas A, Dingjan GM, Savelkoul HF, Kinnon C, Grosveld F, Hendriks RW. The X-linked immunodeficiency defect in the mouse is corrected by expression of human Bruton's tyrosine kinase from a yeast artificial chromosome transgene. Eur J Immunol. 1997;27:2180-2187.

66. Dingjan GM, Maas A, Nawijn MC, et al. Severe B cell deficiency and disrupted splenic architecture in transgenic mice expressing the $\mathrm{E} 41 \mathrm{~K}$ mutated form of Bruton's tyrosine kinase. EMBO J. 1998; 17:5309-5320. 